\title{
J02413
}

\section{放電場と衝撃波の干渉による衝撃波加速現象の投入電力依存性 \\ Input Power effect on Shock Wave Acceleration Phenomena due to Interaction with Discharge Field}

$\bigcirc$ 学 政二 誠幸*1 正 松田 淳*1

鬼頭 卓大 $* 2$ 井上 知樹*3

Tomoyuki MASANI, Atsushi MATSUDA,

Takuhiro KITOU,Tomoki INOUE

*1 名城大学 $* 2$ 日経エムシーアルミ株式会社 *3 東芝インフラシステムズ株式会社

Key Words: Shock wave, Discharge, Mechanical Engineers

\section{1.緒言}

近年、超音速流れ場へのエネルギー注入による衝撃波制御 技術が注目されている.本技術は放電等による変調密度場と 衝撃波の干渉時による衝撃波形状の変調を利用するもので ある。

本技術の実機応用に向けて,密度変調場と衝撃波干渉時に 生じる流体力学的効果の現象理解が不可欠である.過去の衝 撃波可視化実験おいて,衝撃波加速現象による形状変化の温 度依存性が確認された.*1

そこで本研究では,衝撃波加速現象のより踏み込んだ議論 に向けて数值解析を用いた考察を行った.

2.解析方法

\subsection{CFD における支配方程式}

支配方程式は式(1)で示される 2 次元 Euler 方程式である. 解析スキームは Yee の SymmetricTVD 法を用いた。

時間積分は 1 時精度 Euler 陽解法により行った。

$$
\frac{\partial \widehat{Q}}{\partial t}+\frac{\partial \widehat{E}}{\partial \xi}+\frac{\partial \widehat{F}}{\partial \eta}=\mathbf{0}
$$

保存量 $\hat{Q}, \xi$ 方向の流速 $\hat{E}, \eta$ 方向の流速 $\hat{F}$ は式(2)で表される.

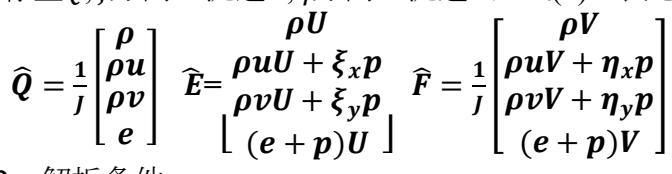

\section{2 解析条件}

Fig.1 は計算領域及び境界条件を示したものである.計算領 域は x,y 方向にそれぞれ $0.05[\mathrm{~m}], 0.032[\mathrm{~m}]$ としている.

境界条件は図のように領域左端はランキン・ユゴニオの関 係式を用いてマッ八数 2.0 の垂直衝撃波を右側一伝播させる 条件を,右側は開境界条件を与えた.更に上端・下端において は滑り壁境界条件とした。

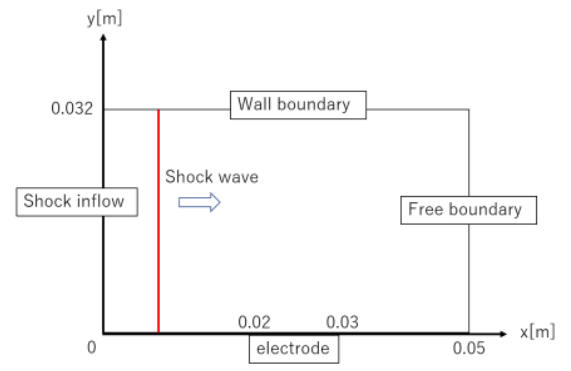

Figure 1 解析領域及び境界条件

また初期条件として計算領域全体に温度 300[K],圧力 $2000[\mathrm{~Pa}]$ の值を与え,放電による温度分布は単純ガウス型分 布となっている.

本稿では Fig.2 のように放電場無しの $\mathrm{T} 0=300[\mathrm{~K}]$,放電によ
る最大温度が $\mathrm{T} 1=1000[\mathrm{~K}], \mathrm{T} 2=2000[\mathrm{~K}]$ の 3 パターンで壁面付 近の衝撃波の加速について調査した。

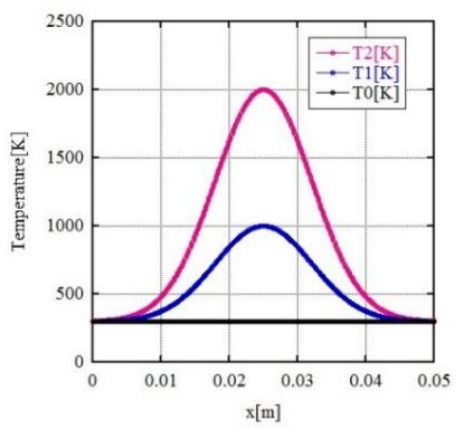

Figure $2 x$ 方向温度分布

3 結果

Fig.3 は衝撃波位置と時間履歴を x-t 線図にしたものである. 左が解析結果,右が実験結果である.両者を比較すると衝撃波 の加速は電極付近で顕著になっており,またより大きな投入 電力であるほど加速も大きくなっていることがわかる.

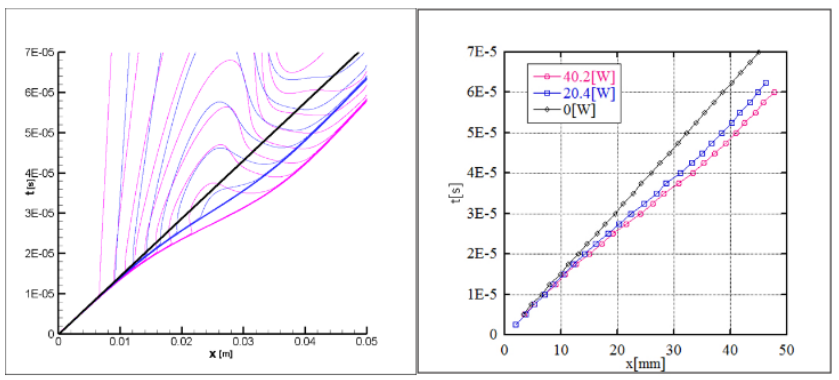

Figure 3 x-t 線図比較

4.結言

ガウス温度分布モデルを用いて衝撃波伝播に関する数值 解析を行った結果と可視化実験結果を比較した結果,電極付 近での衝撃波加速現象が定性的に一致していることが確認 できた。

今後は可視化実験における衝撃波背後渦度のスケール推 定に向けて,衝撃波形状変化亡背後に誘起される物理量との 関係について CFD に基づきより詳細な調査を行うのが課題 である.

5.参考文献

[1]鬼頭 卓大,一次元リーマン問題適用による放電場温度計 測可能性の実験的検討,名城大学,(2018) 